\title{
Costs, Capabilities, Conflict and Cash: The Problem of Technology and Sustainable Economic Growth in Pakistan
}

\section{Matthew McCartney*}

\begin{abstract}
Growth in Pakistan has been surprisingly sustainable. GDP growth of 5 percent p.a. since independence and no recession since (at least) 1960 according to World Bank data represents a creditable performance when compared to all but the most successful developing countries. Pakistan has significantly transformed the structure of its economy during these same decades; in 195099 percent of its exports were agricultural goods and by the 1990s exports were largely manufactured goods. This very success indicates a growing constraint on sustaining growth into the future or the concern that Pakistan may be headed for a Middle Income Trap. Although there does exist scope for continued growth based on further structural changes - in particular the large number of people still employed in agriculture or the women not currently engaged in the labor force - for growth to be sustained a more intensive or productivity-oriented growth will be necessary. This paper first outlines the importance of productivity growth for sustaining GDP growth in Pakistan, then examines the historical and comparative productivity performance of Pakistan, and explores a number of case studies of successful technological change, particularly in South Asia, and finally attempts to draw some lessons for contemporary Pakistan.
\end{abstract}

Keywords: Technology adoption, productivity, political economy, Pakistan.

JEL classification: O14, O49, Q16.

\section{Introduction}

The word technology derives from the Greek word technología, which means 'systematic treatment'; it is derived from the word tekhne, meaning art or craft. This paper uses a similar broad understanding of technology, defining it here as the 'application of practical sciences to industry or commerce.' The examples of technology discussed in this paper range from new dies used in producing soccer balls (footballs) to new seed types in agriculture and new management practices in textiles.

\footnotetext{
* University of Oxford.
} 
Long before the ancient Greeks derived the word 'technology', Pakistan was a global center of technological innovation. In the use of metal saws, drills and firing and glazing techniques, Harappa led the world in necklace technology between 3300 and 2800 BC (Kenoyer, 1997). Since then, Pakistan's technological record has been more mixed. The focus of this paper is to better understand that (contemporary) record of utilizing technology to boost productivity. The paper does not consider the impact of technology on, for example, working conditions, employment and the environment; the focus is more narrowly on growth rather than bigger questions of development and wellbeing.

This paper starts on an optimistic note. GDP growth in Pakistan has been surprisingly sustainable, averaging 5 percent per annum since independence. There has been no economic recession since (at least) 1960, according to World Bank data. This represents a creditable performance when compared to all but the most successful developing countries. Pakistan has significantly transformed the structure of its economy during these same decades: in 1950, 99 percent of its exports were agricultural goods and by the 1990s exports were largely manufactured goods. This very success indicates a potential constraint to sustaining growth into the future. Although there is scope for continued growth based on further structural changes (in particular, the large number of people still employed in agriculture or else the women not currently engaged in the labor force), for growth to be sustained, a shift to productivity-led growth will be necessary.

Section 2 outlines the statistical record of sustainable growth in Pakistan. Section 3 shows how economics represents technological change. Section 4 outlines the (poor) productivity record in Pakistan. Section 5 discusses four key constraints to technology adoption and absorption in contemporary Pakistan: resources (or cash), foreign direct investment (FDI) (costs), learning (capabilities) and conflict. Section 6 concludes by arguing that the outlook for Pakistan is pessimistic: it lacks the ability to mobilize resources or leverage FDI to transfer technology as well as the state necessary to either promote learning or control the conflict associated with technological change.

\section{Sustainable Economic Growth in Pakistan}

Contrary to the assumptions of many, economic growth in Pakistan since independence has been a model of sustainability. Since 1950, GDP growth has averaged around 5 percent per annum - almost exactly the 
same as in India. Table 1 shows that, over the last 20 or so years, GDP growth in Pakistan has not quite reached the levels of India and China, but compares favorably with other large Asian economies, including Indonesia, Thailand, Hong Kong and South Korea.

Table 1: GDP growth, 1990 to 2011

\begin{tabular}{lc}
\hline Country & GDP growth rate (\%) \\
\hline Pakistan & 4.3 \\
China & 9.9 \\
India & 7.2 \\
Indonesia & 5.2 \\
Thailand & 4.1 \\
Hong Kong & 4.0 \\
South Korea & 4.0 \\
\hline
\end{tabular}

Source: Asian Productivity Organization (2013, p. 18).

Figure 1 confirms that, while GDP growth has slowed on various occasions, particularly during the early 1970s, early 1990s and late 2000s, there has not been an economic recession (negative GDP growth) since at least 1960. India, by comparison, has had numerous recessions. Unlike most of the rest of the world, Pakistan has sustained positive growth through the 1973 and 1979 oil price shocks, the 1982 world recession and ensuing global debt crisis, the 1997 Asian crisis and the 2008 global financial crisis. The graph also demonstrates that GDP growth in Pakistan has fluctuated around a relatively narrow band, typically between 4 and 8 percent, and more recently between 2 and 4 percent.

Figure 1: Annual GDP growth in Pakistan, 1960 to 2015

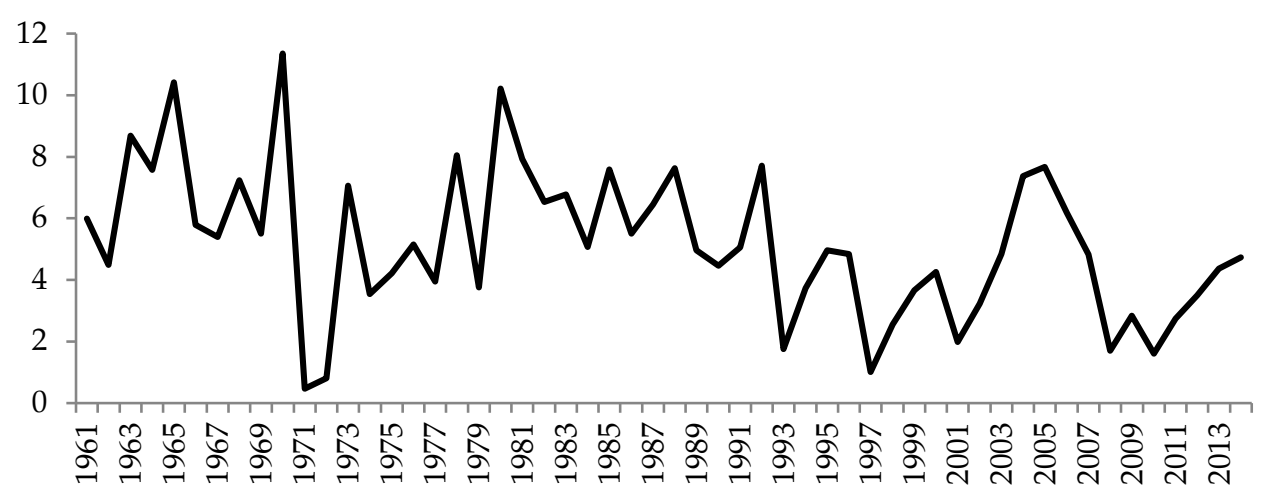

Source: World Bank (2016). 
For comparison, Figure 2 shows GDP growth in Malaysia over a similar time period. Average growth in Malaysia has been more rapid than in Pakistan, typically in the 5-10 percent range, but it has also been more unstable. There have been at least three recessions in Malaysia since 1960, most notably the -7.4 percent experienced during the Asian crisis in 1997.

Figure 2: GDP growth in Malaysia, 1960 to 2015

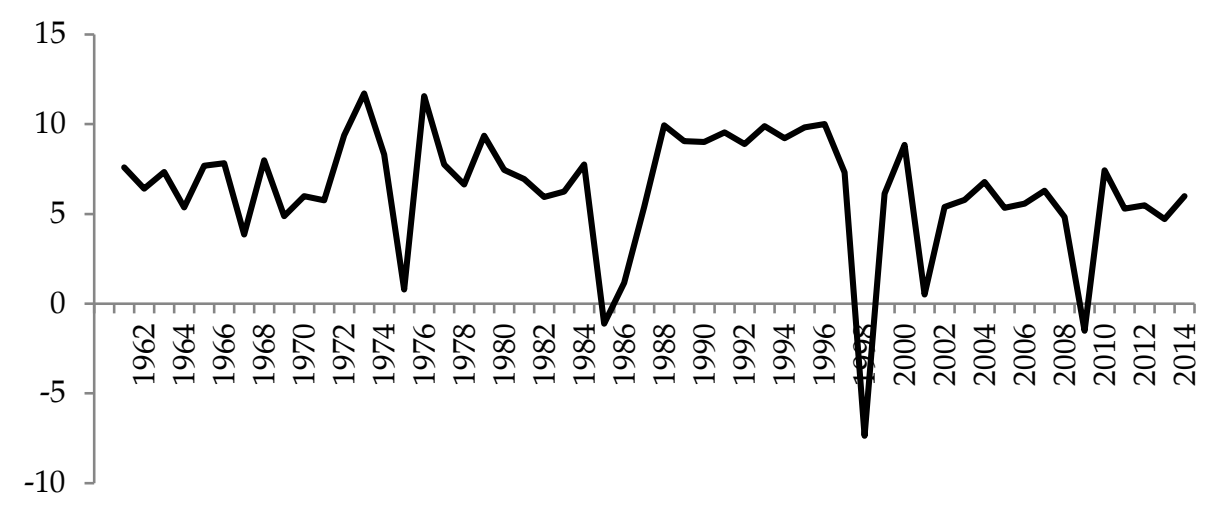

Source: World Bank (2016).

\section{The Representation of Technological Change}

This section shows how economics represents the process of technological change and, in particular, how technology can overcome diminishing returns to investment and so, permit sustained economic growth. Figure 3 demonstrates the impact of technological change on GDP. At any given level of the capital stock (or quantity of land or labor), technological change leads to higher output (yield of land or labor productivity). At point $\mathrm{A}$, sustaining growth through more investment becomes difficult whereas technological change, by raising the productivity of the existing capital stock, increases income from GDP1 to GDP2. This shows how technological change can help make growth sustainable. 
Figure 3: Sustained growth and technological change

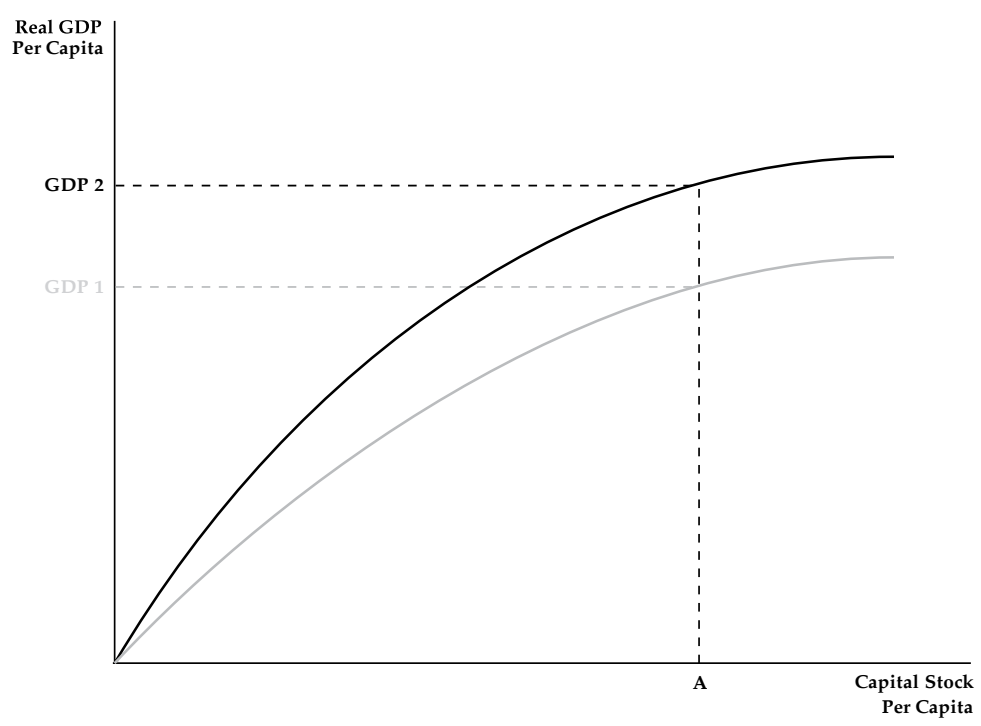

Note: Thanks to Rajat Raj for drawing the graph.

Figure 3 captures an important stylized feature of growth in Pakistan over the last several decades and for the next few decades. Growth in a low-income developing country such as Pakistan in 1950 can be sustained over several decades by raising the rate of capital accumulation (investment), particularly when that capital helps shift the structure of the economy away from low-productivity agriculture to higher-productivity industry. This broadly represents what happened in Pakistan from the 1950s to the 1990s or, more stylistically, up to point A in Figure 3. Once a country has made the transition from a poor agrarian economy to a low middle-income country (as had Pakistan by the 1990s), to sustain growth and avoid diminishing returns to investment requires a shift to growth based on productivity rather than ever higher levels of investment. Failing to make the transition has become known as being caught in a 'middle-income trap' (Kharas \& Kohli, 2011; Felipe, Abdon \& Kumar, 2012).

Figure 4 maps two alternative future scenarios for Pakistan. Both South Korea and Brazil experienced rapid economic growth in the 1960s and 1970s. After 1980, South Korea managed to sustain economic growth through a successful transition to productivity-led growth while Brazil saw its growth falter and GDP per capita remain stagnant for the next three decades at the middle-income level. 
Figure 4: Brazil and South Korea, GDP per capita (constant 2005 US\$)

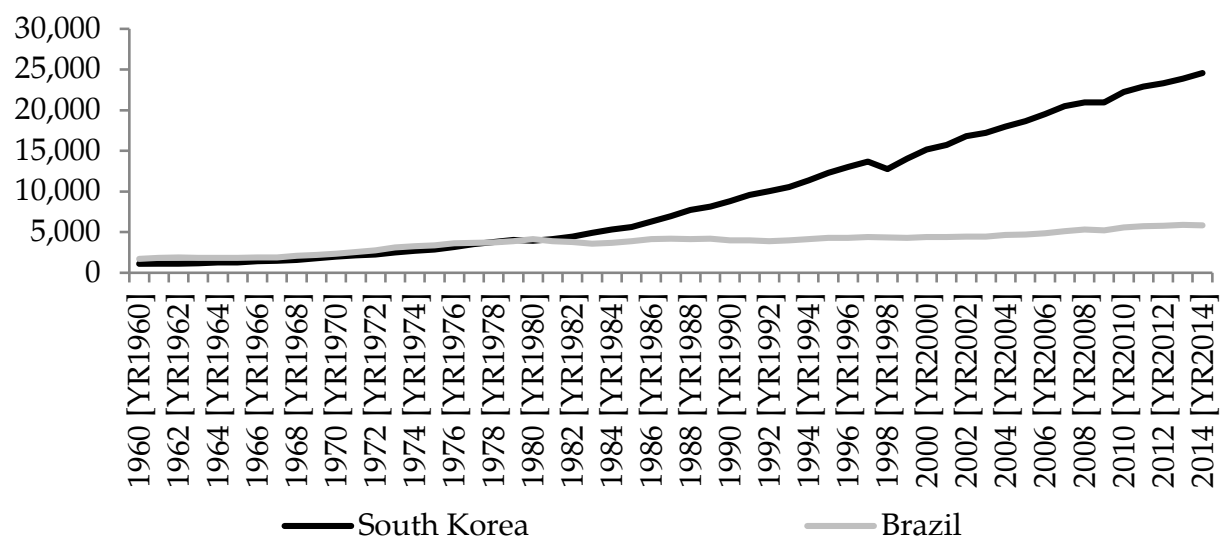

Source: World Bank (2016).

\section{Pakistan: Technology and Productivity}

There has been a long debate in economics as to the extent to which total factor productivity (TFP) growth is determined by the adoption and absorption of new technologies and to what extent it is explained by other factors. Other factors may include access to better raw materials or improvements in the quality and motivation of the labor force. For the sake of this paper, I assume a close link between technology and productivity growth. This paper is concerned with sustainable growth; the other potential impacts on productivity are either one-off events (such as improving management practices) or themselves may run into diminishing returns (improving the education level of the workforce).

The evidence for Pakistan is pessimistic. Since at least the mid1960s, it has experienced slow growth of productivity. There is supporting case study evidence to suggest that Pakistan has generally failed to upgrade to new technologies since at least the early 1970s within particular economic sectors. Productivity growth during the 1960s was quite rapid in rubber, tobacco, textiles, printing and publishing and electrical machinery, and only in the paper industry was productivity growth negative (Cheema, 1978). A more general index of productivity - TFP measured in two ways for Pakistan confirms this rapid growth from the mid-1950s to the early or mid-1970s, followed by a continuous decline until the early 1990s (Wizarat, 2002, pp. 76-77). Table 2 shows that, between 1955 and 1991, growth in Pakistan was driven by more capital and labor and economies of scale while technological change/productivity had a negative impact. 
Table 2: Sources of growth/decline estimates, 1955 to 1991

\begin{tabular}{lc}
\hline Sources of growth/decline & Percentage contribution \\
\hline Capital & 88.16 \\
Labor & 39.82 \\
Technological change & -27.26 \\
Economies of scale & 42.86 \\
Residual & -43.58 \\
Total & 100.00 \\
\hline
\end{tabular}

Source: Wizarat (2002, p. 95).

Table 3 shows that, over the long term (1970-2011), TFP growth in Pakistan has been low. Of particular concern is the sharp slowdown of TFP growth in Pakistan in recent years while TFP growth has tended to accelerate in comparator countries.

Table 3: TFP growth, 1970 to 2011

\begin{tabular}{lcc}
\hline Country & $\mathbf{1 9 7 0 - 2 0 1 1 ~ ( \% )}$ & $\mathbf{2 0 0 5 - 1 1 ( \% )}$ \\
\hline Pakistan & 1.4 & 0.6 \\
Thailand & 1.8 & 1.3 \\
China & 3.2 & 4.2 \\
India & 1.4 & 3.9 \\
South Korea & 1.7 & 2.4 \\
\hline
\end{tabular}

Source: Asian Productivity Organization (2013, pp. 76-77).

A crucial part of this general failure of productivity has been the slow growth of labor productivity. Table 4 shows that labor productivity growth in Pakistan has long been much slower than in comparator countries and slowed down in recent years.

Table 4: Labor productivity growth, 1990 to 2011

\begin{tabular}{lcc}
\hline Country & $\mathbf{1 9 9 0 - 2 0 0 0 ~ ( \% )}$ & $\mathbf{2 0 0 0 - 1 1 ( \% )}$ \\
\hline Pakistan & 1.9 & 1.3 \\
China & 8.9 & 9.3 \\
India & 3.0 & 5.5 \\
Thailand & 3.9 & 2.2 \\
Bangladesh & 3.3 & 1.0 \\
South Korea & 5.2 & 4.2 \\
\hline
\end{tabular}

Source: Asian Productivity Organization (2013, p. 66). 
In manufacturing, Raheman, Afza, Qayyum and Bodla (2008) find that TFP growth was very slow (0.9 percent per annum) between 1998 and 2007. This was promoted by technical efficiency (using factors more efficiently in production), but undermined by technical change (the very slow adoption of new technology). Importantly for Pakistan, its key export sector, textiles, suffered negative TFP growth in the weaving, spinning and composite subsectors. More specific case study evidence finds, for example, that small firms in Gujranwala are characterized by low levels of technical efficiency. The percentage of firms that are technically efficient ranges from a low of 18 percent in knitting mills to a high of 59 percent in saw and planing mills (Burki \& Terrell, 1998).

Another study finds that technical efficiency did improve slowly over the 1990s in diverse sectors, including textiles, foods, industrial chemicals, iron and steel, drugs and pharmaceuticals, electrical machinery and nonelectrical machinery. It also finds, however, that large gaps in efficiency remained in these sectors by the early 2000s. In many other sectors, such as glass and glass products, transport equipment, tobacco, nonmetallic mineral products and other chemical products, technical efficiency continued to decline (Din, Ghani \& Mahmood, 2007).

\section{Pakistan: Constraints to Technology Adoption and Diffusion}

Section 4 shows that there has been a longstanding productivity problem in Pakistan. Sustained economic growth over 50 years has occurred despite slow productivity growth since at least the early 1970s. This failure was hidden by the relatively high levels of investment that drove economic growth and structural change. The consequences of this failure are likely to be more evident in the coming decades. Pakistan has reached the lower middle-income level (point A in Figure 3) and there is now much less scope for further growth based on investment without productivity. The country faces a real risk of following the Brazilian path of stagnation rather than the Korean path of continued sustained growth (Figure 4).

This section examines four important influences on the pace of technology acquisition - and so, on productivity growth - and evaluates their likely impact for contemporary Pakistan. These are resources (cash), FDI (costs), learning (capabilities) and conflict. The paper will conclude that the outlook for Pakistan is pessimistic: its prospects may be more like Brazil than South Korea. 


\subsection{The Availability of Resources (Cash)}

Much technology is 'embodied'. This means that new technology requires an act of investment for it to be used. For example, new and improved computing technology requires that a potential user invest in a new computer to access that technology. So, while investment and productivity growth are conceptually distinct (Figure 3), in practice there is a close link between the two.

There is broad evidence to demonstrate the importance of resource mobilization for investment and so, for technology acquisition. ${ }^{1}$ A sample of 32 countries reveals the significant and positive impact of public savings on GDP growth (Krieckhaus, 2002). The stagnation of Brazil and rapid growth of South Korea (and Singapore) are both linked to distinct stories of savings. The slowdown of growth in Brazil after 1980 (Figure 4) is directly linked to a weakening of the central state and a rise in populist and politically motivated public spending, and hence to lower public saving and public investment (Weyland, 1998).

In South Korea, the government was successful in mobilizing tax revenue, which increased from 7 percent of the gross national product (GNP) in 1964 to 16 percent in the 1970s. This, combined with tightly controlled current expenditures, allowed government savings to increase from 0 percent of GDP between 1961 and 1965 to 5.5 percent between 1966 and 1970 (Kohli, 2004, p. 103). The government was also able to repress private consumption through policy measures such as controls on consumer loans and high rates of indirect taxation. Imports of luxury goods were banned or subject to high tariffs and inland taxes (Chang, 1993, p. 139). The private savings rate in South Korea increased from 6.8 percent of GNP between 1961 and 1965 to 18.0 percent between 1976 and 1980 (Kohli, 2004, p. 103).

In Singapore, public savings were generated by the government in two ways: by manipulating the prices charged by public utilities such as

\footnotetext{
${ }^{1}$ It is not just a question of the volume of resources. There is good evidence of significant political interference in the allocation of these low levels of saving via bank lending in Pakistan. One estimate finds that politically influential firms - defined as a situation in which a firm director participates in an election - borrow 45 percent more and default 50 percent more than nonpolitical firms. The survey estimates that the economy-wide impact of this distortion amounts to around 0.31.9 percent of GDP a year (Khwaja \& Mian, 2005, p. 1371). The accumulated impact over time of such misallocation is likely to be significant. Though not tying their results to just politically motivated lending and investment, Hsieh and Klenow (2007) estimate that aggregate productivity would increase by $40-50$ percent in India were investment in capacity expansion to have been allocated as efficiently as in the US.
} 
telecommunications to raise a surplus for the state (Huff, 1995, p. 745; Ermisch \& Huff, 1999) and by controlling private consumption, which by 1995 comprised only 40.9 percent of GDP (by comparison, the lowest ever share reached by the USSR was 55 percent). The total savings rate rose from 6.7 percent of GDP between 1960 and 1966 to nearly 43 percent in the 1980s (Huff, 1995, p. 737).

In these successful Asian economies the link from public savings to economic growth is argued to have run through higher public investment in infrastructure, education and support to technology transfer and absorption from abroad (Nelson \& Pack, 1999).

Pakistan has a much more mixed record in translating public savings and so public investment into productivity and so economic growth. Higher public investment did increase economic growth in the early 1960s and early 2000s, in the latter this was undermined by falling US aid after 1965 and in the latter by domestic political conflict and the 2008 global financial crisis. By contrast, sharp increases in public investment under Zulfikar Bhutto in the 1970s provided both infrastructure and cheap inputs to industry. This should have relieved constraints on industrial growth that had been widely noted by the late 1960s, but there was no increase in GDP growth. Bhutto's nationalization campaign and anti-private sector rhetoric undermined the confidence of investors, and led to a collapse in private investment that offset the growth benefits of higher public investment (McCartney, 2011).

The contemporary Pakistan experience is strikingly different. Figure 5 shows that a significant gap between investment (gross capital formation) and savings (gross domestic savings) in Pakistan opened up in 2005. At its peak in 2009, this amounted to around 12 percent of GDP. In 2014, it was still around 7-8 percent of GDP. This implies that Pakistan depends on generating a surplus elsewhere to fund investment. 
Figure 5: Savings and investment in Pakistan, 1990 to 2015

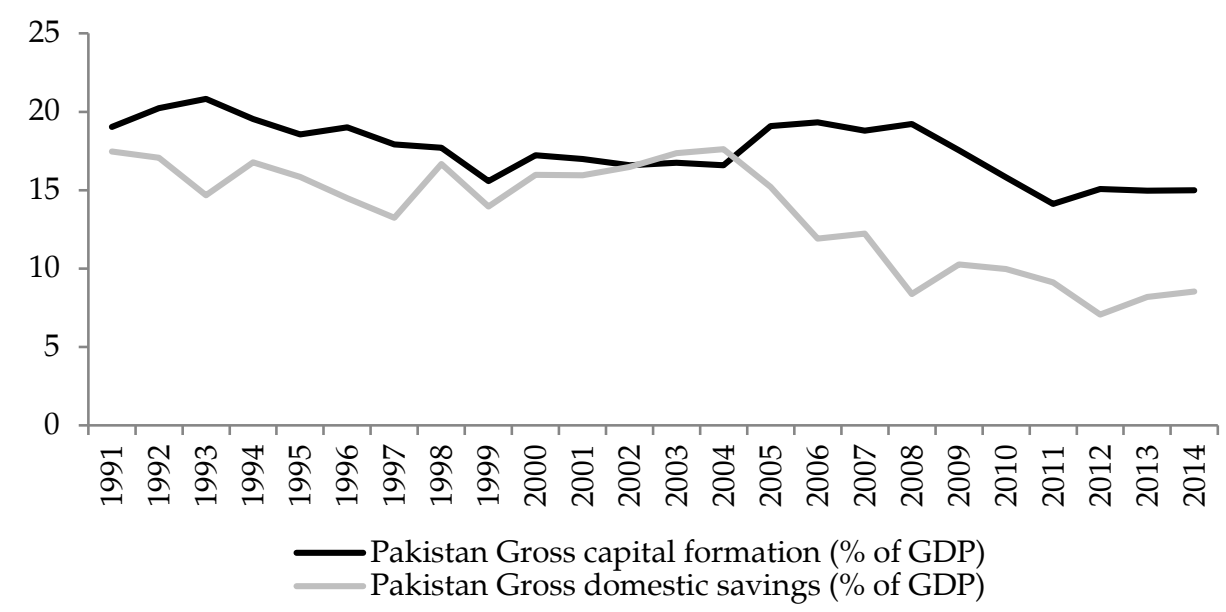

Source: World Bank (2016).

Figure 6 shows that this surplus is not coming from the government sector. Since the mid-2000s, a long-standing surplus of tax revenue over government consumption spending has turned into deficit. This means that the government has to borrow to fund all its investment and even some of its consumption spending.

Figure 6: Government consumption and tax revenue in Pakistan, 1990 to 2015

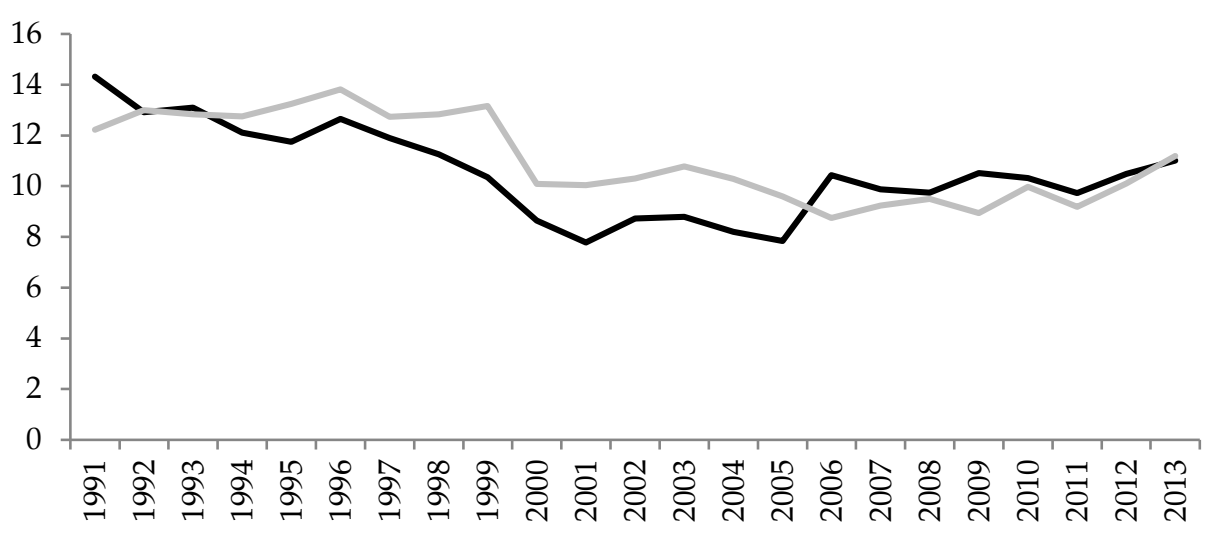

- Pakistan General government final consumption expenditure ( $\%$ of GDP) Pakistan Tax revenue (\% of GDP)

Source: World Bank (2016). 
Together, Figures 5 and 6 imply that Pakistan is structurally dependent on external resources to fund domestic investment and so, to acquire any technology embodied in that investment. In the 1970s, this structural imbalance was met through remittance transfers from Pakistanis working overseas, mainly in the Gulf region. In the 1980s, it was met through foreign aid linked to Pakistan's alliance with the US against the intervention of the USSR in Afghanistan. In the 1990s, the accumulation of expensive foreign debt helped close the gap. In the 2000s, this deficit was initially met through sharply rising levels of FDI and remittances and, to a smaller extent, by debt forgiveness linked to Pakistan's support for the USled 'war on terror' in Afghanistan. After 2008, it was met increasingly through foreign borrowing (McCartney, 2015).

The first constraint to Pakistan's ability to shift to productivity-led growth is either to raise sufficient savings and tax revenue domestically or to hope for a favorable international geopolitical situation that enables a long-term stable transfer of resources from abroad. Given the very longstanding failure to mobilize tax revenue in Pakistan and the vagaries of the global geopolitical environment and associated aid flows, there is no easy solution (McCartney, 2012).

\subsection{FDI and Technology Transfer (Costs)}

FDI may lead to technology transfer among local firms that can imitate or copy that technology. Workers trained by a multinational may transfer knowledge to a local firm or start their own firms and take with them the relevant technological know-how. The magnitude of such positive spillovers from FDI has been found to depend on local skill endowments, the capability of local education and research institutions, the technological capability of local firms and the provision of infrastructure (Lall, 1992; Gorg \& Greenaway, 2004). There is ample evidence that successful developing countries have long leveraged FDI as a source of technology transfer; these include Japan (Johnson, 1982), South Korea (Mardon, 1990), Singapore (Huff, 1995; Ermisch \& Huff, 1999) and Ireland (Ó Riain, 2000).

Pakistan has recently had an excellent opportunity to leverage FDI to acquire new technology. Figure 7 shows that there was a boom, if temporary, in FDI inflows to Pakistan after 2003. 
Figure 7: FDI net inflows in Pakistan (current US\$)

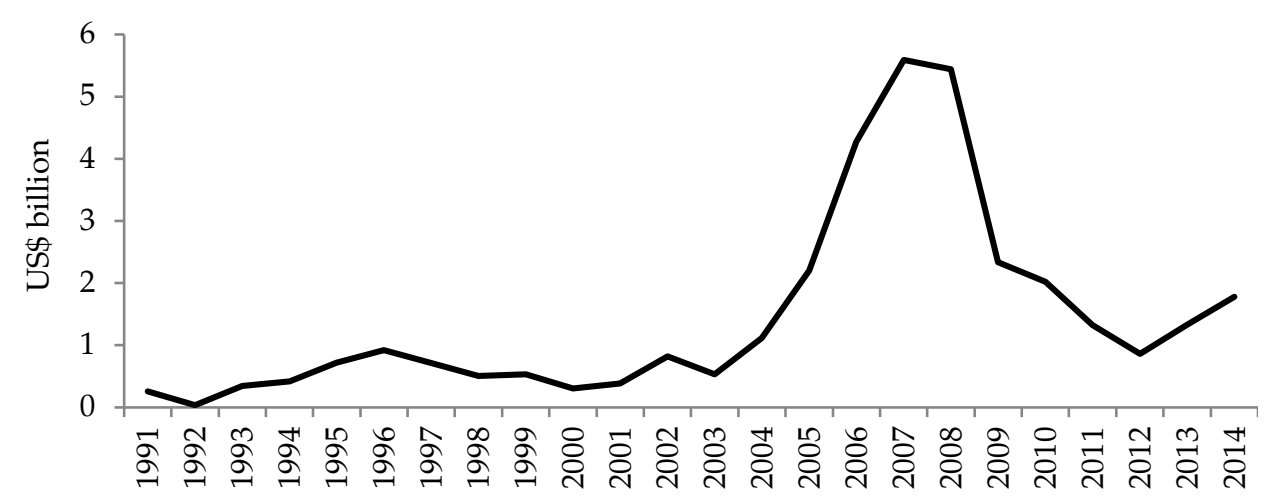

Source: World Bank (2016).

As noted above, technology transfer from FDI has been found to depend on, among other things, the stock of educated and skilled labor. In 2003/04, as the FDI boom started, only 52 percent of the population of Pakistan aged 10+ years were literate, including 40 percent of females (Khan, 2009). There are also concerns with the quality of education beyond the minimal criteria of literacy. The 2003 Learning and Educational Achievement in Punjab Schools project found that, by the end of grade 3, less than 20 percent of its sample of 12,000 children could understand a simple written sentence in the vernacular and less than 10 percent could graphically represent simple information (bar charts) compared to over 70 percent internationally. In summary, "close to onehalf of the three million born in Pakistan will leave school unable to add, subtract, multiply or divide, unable to read and write simple sentences in Urdu; and unable to read a short word like "BALL" in English" (Das, Pandey \& Zajonc, 2012, p. 232).

Pakistan also fails with regard to the vocational education that could have created the practical skills needed to absorb technology from FDI. By the mid-2000s, it had 3,125 technical and vocational institutions with a total enrolment of 256,000 . The curriculum had little relevance to the evolving labor market and practical training was near absent. The Government Polytechnic Institute in Karachi, the oldest such institute in existence, offered training in 17 different trades, but by mid-2009 was in a state of disrepair (Khan, 2009).

Many authors agree that developing countries such as Pakistan are, today, severely constrained in their ability to leverage FDI to promote 
technology transfer. ${ }^{2}$ Wade argues that developing countries are now more "tightly constrained in their national development strategies by proliferating regulations formulated and enforced by international organizations" (2003, p. 621).

The agreement on trade-related investment measures (TRIMs) that emerged from the Uruguay Round of GATT-WTO trade negotiations in the mid-1990s aimed to remove those 'trade and investment distortions' which, argue Chang and Wade, have long been used by developing countries to promote investment and technological absorption by national firms. An example would be local content agreements by which FDI firms are compelled to source an increasing proportion of their inputs from local firms over time.

These concerns are overstated. TRIMs prohibit measures that (i) require particular levels of local sourcing by an enterprise, (ii) restrict the volume or value of imports that an enterprise can buy/use to the volume or value of products it exports, (iii) restrict the volume of imports to the amount of foreign exchange inflows attributable to an enterprise and (iv) restrict the export by an enterprise of products to a proportion of the volume/value of local production (Di Caprio \& Amsden, 2004).

This list of restrictions leaves open various other routes to promoting domestic industrialization and technology acquisition. Developing countries can support their own industries, target national champions and promote general national competitiveness in the name of 'promoting science and technology'. Various subsidies are permitted for R\&D (including innovation and technological upgrading), disadvantaged subnational regions and environmental upgrading (Weiss, 2005). The main constraint is not international law but domestic politics and "the most coercive part of the new international economic order is informal" (Amsden \& Hikino, 2000, p. 110). Rarely do contemporary developing countries - certainly including Pakistan - have a committed faction among the political and civil service elite capable of articulating and promoting an industrial policy to promote technology absorption.

A recent example of this failure is the Pakistan Textiles Policy 200914 produced by the Ministry of Textiles. This was an explicit effort to boost technology acquisition. The policy recognized numerous of the constraints faced by the textiles industry, such as the lack of adequate infrastructure

\footnotetext{
${ }^{2}$ See McCartney (2014) for a more extended discussion.
} 
and skilled labor, and that the regulatory framework increased the cost of doing business. The plan lacked any clear focus. It was less a plan than a long list of aspirations, including to "develop state-of-the-art infrastructure facilities"; to "increase the supply of efficient human resources"; to "evolve a legislative framework that sets standards for each stage of processing" with a view to "increasing productivity" and "improving quality", thereby "ensuring optimum utilization of resources"; to "promote R\&D" to "achieve product diversification", "technological advancement" and "increased productivity throughout the value chain", specifically in the "quality and diversity of fibers"; and to "encourage exports by meeting the demands of competition, technology and higher labor productivity".

This effort was costed at US\$8 billion (largely for the private sector) over five years and a government-sponsored 'Textiles Investment Fund' was promised. Areas for government funding were to include the modernization of machinery and technology, removing infrastructure bottlenecks, enhancing skills, better marketing and the use of IT. The funding was all-purpose to encourage manufacturers in all subsectors to modernize their machinery and technology. This aim did not target the key market failure in the risk associated with learning and technology acquisition (Section 5.4). Funding was not targeted at risk but at "reducing the cost of financing to international levels and ensuring adequate availability of credit for such purposes". Support was also promised "to attract joint ventures, mergers and FDI for expansion and upgrading in the sector". The policy subsequently fizzled out in response to budget cuts and pressure from the International Monetary Fund to reduce public spending. Resources are needed to promote technological change (Section 5.1).

\subsection{Technology and Learning 3}

Simplified models of technological transfer assume that technology is freely available to all countries/firms. More labor-abundant countries, for example, will select labor-intensive technology to take advantage of their low wages; once selected, this new technology can be either costlessly absorbed or else any learning period is predictable and automatic (Lall, 1992, 1994). In reality, markets within which international technology transfer takes place are subject to various market failures, such as asymmetric information, the market power of technology producers, and externalities in learning (Lall, 1992, 1994; Hoekman, Maskus \& Saggi, 2005).

\footnotetext{
${ }^{3}$ This section is largely drawn from McCartney (2014).
} 
Given these market failures, there may be a valid case for intervention on the infant industry basis whereby industries or firms that have the potential to be competitive need nurturing through the early stages of learning. Much of the technological and organizational knowledge necessary for competitiveness is tacit knowledge embedded in routines. Effective production requires a mix of formal or codifiable knowledge (can be communicated in words/symbols) and uncodifiable knowing-how-to embedded in unconscious and often complex routines (tacit knowledge) (Khan, 2013a). It takes time to experiment and integrate new machines into production in an optimal manner and requires learning-by-doing. The key market failure is, therefore, a financing problem - that period of risk and loss making that has to be financed while learning-by-doing is taking place. Own investment by the firm will be limited to the availability of retained profits and the owner's willingness to undertake the risk.

In theory, private investors could be lured by the prospect of future profits and finance that loss making. In reality, this does not often happen. Private investors are happy to finance investment in known sectors where the market is assured and the methods of production are standardized. In Bangladesh, for example, survey evidence shows that there is no shortage of bank finance, which is readily available for established technologies and entrepreneurs (Khan, 2008). In the World Bank (2007) Enterprise Survey, only 17.7 percent of Pakistani firms surveyed reported access to finance as a major constraint, compared to 33.4 percent in other South Asian countries and 29.7 percent across 135 countries.

Learning to use new technology to raise productivity requires significant effort by managers and workers (Khan, 2011). A firm could contract with a bank to supply this requisite effort in return for lending and repay the loan from future profits. Accurate disclosure of profits and enforcing the rights of outside investors (such as banks or shareholders) is difficult to ensure in a developing country. In theory, enforcing the rule of law, reducing corruption and increasing transparency can help enforce such contracts, but this is likely to take a long time.

In Bangladesh, survey participants were asked which mechanisms of good governance reforms would solve their problems - such as a more efficient stock market allowing them to raise funds - and "they universally agreed that these conventional mechanisms were implausible even in the medium term" (Khan, 2008, p. 21). In Pakistan, less than 1 percent of firms in 2007 financed investment by equity or stock sales (World Bank, 2007). In 
practice, banks try to protect themselves by requiring high-quality collateral and high interest rates from borrowers, which passes on the risk from the bank to an entrepreneur-owner. Survey evidence in Bangladesh confirms that firms were concerned about the high interest rates even for loans backed by good collateral, the combination of which shifted the risk of delay and problems with new technology to the borrower (Khan, 2008).

A second solution would be to target incentives more closely to the mechanics of the learning failure. A firm could obtain a subsidy or cheap credit that would allow it to engage in learning-by-doing. The conditions of rent withdrawal would need to be clear from the outset so that owners and managers feel compelled to put high levels of effort into learning (Khan, 2013b). In 1960s South Korea, technology was mainly transferred to large firms (chaebols) that received various forms of subsidies (often cheap credit) and protection from imports to give them an opportunity to expand production. Increased production was closely linked to learning-by-doing as subsidies and protection were conditional on firms meeting export targets, reducing costs and absorbing new technologies. The state maintained a credible threat to remove these incentives should firms fail to meet their targets. The balance of power between the state and chaebols was such that inefficient firms were not able to protect their subsidies if the state wanted to withdraw them (Khan \& Blankenburg, 2006).

The state needs to have administrative capacity and political willingness to allocate subsidies that are contingent on learning and to remove them in the event of failure. For South Korea, those successful preconditions are usually framed in terms of it having been a 'developmental state'. A developmental state is defined as "states whose politics have concentrated sufficient power, autonomy and capacity at the center to shape, pursue and encourage the achievement of explicit development objectives, whether by establishing and promoting the conditions and direction of economic growth, or by organizing it directly, or by a varying combination of both" (Leftwich, 1995, p. 401). 
Table 5: Declining state capacity in Pakistan

\begin{tabular}{lcc}
\hline Measure of governance & $\mathbf{2 0 0 6 / 0 7}$ & $\mathbf{2 0 1 4 / 1 5}$ \\
\hline Quality of institutions & 3.5 & 3.2 \\
Judicial independence & 3.3 & 3.8 \\
Favoritism shown in decisions of government officials & 3.1 & 2.6 \\
Wastefulness of government spending & 3.5 & 2.6 \\
Reliability of police & 3.1 & 3.1 \\
\hline
\end{tabular}

Source: World Economic Forum $(2006,2014)$.

\subsection{Technology and Conflict}

Economic development is about shifting resources from low- to high-productivity areas. During the course of development, the share of the labor force working in agriculture may decline from 90 to 10 percent of the total and land is reallocated from small farms to large farms, to urbanization and to factories. Technological change will also create losers among those whose skills become obsolete, often as a task becomes mechanized. Such workers will lose the status of being skilled craftsmen and perhaps descend into the ranks of unskilled manual laborers (Chang, 1999).

There are two ways of thinking about how such conflict arises. The first relates to New Institutional Economics. Here there exist two agents or groups with different incentives. For example technological change will boost profits for employers but make the skills and hence employment of workers obsolete. Institutional economists would trace the problem to missing institutions, either formal or informal. In the above example the formal institution of an employment contract would give workers job security. Certain of continued employment workers would have no incentive to resist the adoption of the new technology. The firm would implement the new technology and re-deploy the displaced workers elsewhere in the firm and ultimately share the higher profits associated from producing with the new technology. The second relates to the processes of political and social change. For many developing countries, politics after 1945 was characterized by conflict, structured variously through ethnicity, class and geography and manifest through riots, coups, alienation, the loss of authority by the formal legal system and decline of broadly based political parties. There was a decline in political order measured by the declining effectiveness, authority and legitimacy of government. Huntingdon argues that, "in large part it [conflict] was due to rapid social change and mobilisation of new groups into politics and slow development of political 
institutions" (1968:4). Social and economic change such as urbanization, increased literacy, industrialization, and expansion of the mass media had extended political consciousness, multiplied political demands, and increased political participation. The new elites of civil servants and teachers employed by the central government undermined traditional sources of political authority, the secular and religious leaders of the villages, and traditional social networks based around family, class and caste. Economic development also created newly wealthy groups not assimilated into the existing social order. The primary problem of politics and resulting conflict was the slower development of political institutions relative to social and economic change, "economic development and political stability are two independent goals and progress toward one has no necessary connection with progress toward the other." (Huntingdon, 1968, p. 6).

History, though, has demonstrated two means to overcome opposition to technological change: repression of those opposed or a more inclusive form of compensation to the losers. The most famous example of organized opposition to technological change was that of the Luddites. This name recalls a movement that started in Nottingham, England, in 1811 and spread rapidly over the next two years. The participants (allegedly led by Captain Ludd) smashed wool and cotton mills, believing that mechanization had deprived them of employment. The Luddites were brutally suppressed by the government and many participants were executed or transported to Australia (Easterly, 2001a, p. 182). The losers in this case were brutally repressed by a state that used its coercive capabilities to support the process of technological change.

The reallocation of agricultural land from small, low-productivity farms to either larger commercial farms or urban-industrial usage is a key aspect of long-term structural change and the ability of an economy to utilize new technology in farming or industry. Land reallocation offers a contemporary example of both repression and compensation. China has solved this problem by repressive means. One estimate suggests that 20 million farmers were evicted from agriculture as a consequence of land acquisition between 1996 and 2005. This land grab permitted about 5 percent of arable land to be transferred to nonagricultural use, which was crucial in supporting China's growth, based on the export of manufactured goods. The Chinese state has intervened brutally to support the process through the deployment of police and the military. China's ministry of public security acknowledges that 87,000 public order disturbances broke out in 2005 alone, a large proportion of which were due to such land grabs (Sarkar, 2007). 
In Vietnam, the same process of land transfer has relied more on compensation. During the 1990s, Vietnam allocated state-owned land to households through laws in 1988 and 1993 that formally codified this process first and then sought to deal with ensuing problems. These related to local governments that continued trying to control the process of land (re)allocation, the short duration of use rights, lack of transferability and continuing difficulties with using land as collateral. The new laws established the right to inherit, transfer, sell, lease and mortgage land use (though not full ownership) and to receive compensation in case of government expropriation (Deininger \& Jin, 2003). Between 1993 and 1998, the land market had become active. By 1998, 27 percent of households surveyed had received use rights to new land plots through purchase, exchange, inheritance or allocation, and 13 percent had sold, exchanged or returned land.

The land was not just grabbed by politically well-connected groups. Rather, the land market worked to reallocate land to more productive farmers through market sales or renting it out by less to more productive farmers (the compensation) (Ravallion \& Van De Walle, 2006). The increased security in the land rentals market enabled many to leave rural areas confident they could retain ownership-control of land assets. Between 1993 and 1998, the share of households with at least one member with an off-farm job increased from 30 to 55 percent. This formed the pool of labor for employment in the country's rapidly growing export industries (Deininger \& Jin, 2003). This process is reminiscent of many of the arguments made by De Soto (2001), that giving formal ownership titles to informal sector housing, land and business assets will enable their new owners both to turn them into collateral to access banking loans and also give them incentives to undertake long-term investment to improve those assets. Or as De Soto argues, turning dead capital into productive capital.

Contemporary India has (so far) tried and failed to implement both repression and compensation in land transfers. Formal powers of compulsory acquisition were established in India by the Land Acquisition Act 1894, which utilized the concept of 'eminent domain', enabling the state to make compulsory purchase of private assets for public purposes, with compensation linked to market prices. This law was reincarnated as the 2005 Special Economic Zone (SEZ) Act that set a framework for state governments to acquire land for industrial estates. By 2008, 404 SEZs had been approved, covering 54,280 acres. After being launched, many SEZs then stalled in response to massive political protest: these included the Salim Group's petro-chemical SEZ in Nandigram (West Bengal), the 
Reliance Group Multipurpose SEZ near Mumbai and the US\$12 billion POSCO steel SEZ in Orissa (Levien, 2011).

Public infrastructure projects, notably the Sardar Sarovar dam on the Narmada River in Gujarat, also attracted protest. Most famous was the Tata Nano project in West Bengal to build a US\$2,000 car for the Indian mass market. The state-run West Bengal Industrial Development Corporation identified 1,000 acres for Tata; this was estimated to affect the land rights of 12,000 owners (Mohanty, 2007). The government tried to devise a relatively generous compensation scheme, but failed to convince the owners it would be paid. It also failed to include those unregistered sharecroppers and landless households who were dependent on working the land for their livelihoods. By July 2006, the highway bordering the Singur site was blocked by protestors. By September, the police began resorting to violence; in November, Special Forces had been sent in to protect the site (Mohanty, 2007; Sarkar, 2007).

In response, the central government put together the first policy on resettlement and rehabilitation in 2004, which was revised in 2007 after these widespread protests. It re-emerged as the Right to Fair Compensation and Transparency in Land Acquisition, Rehabilitation and Resettlement Act 2013 and came into force on 1 January 2014. The legislative tendency was to increase the attention given to more carefully quantifying the costs and benefits to society at large and the impact on affected families in a participatory and transparent manner. Whether it will work in a similar manner to Vietnam remains to be seen.

A case study by Atkin et al. (2015) of the hand-stitched soccer-ball (football) cluster in Sialkot gives a specific example of this problem for contemporary Pakistan. This micro-level case study raises interesting questions about how best Pakistan can learn from historical and contemporary examples on how best to promote technological change when workers resist it. Options are to resort to repressive measures, that is to introduce the new technology and sack workers who oppose its adoption (China style), or else to introduce the technology via a process of consultation and compensation through ensuring that the benefits are shared between employer and employee (Vietnam or India style). The issue identified in Atkin et al. (2015) is that the 130+ firms in the industry cluster have been very slow to adopt a new technology (a new die) that offers a significant reduction in mean costs relative to existing (low profit) margins and would occur in an industry facing highly competitive international markets (mainly China) producing a relatively standardized 
product, using a simple, standardized production process. Atkin et al. hypothesize that the explanation for this puzzle is related to incentives within the firm. The new die reduces the productivity of cutters and printers during the initial period as they learn to use the new technology. As cutters and printers are generally paid a pure piece rate, their real wage would likely fall in the short run, giving them an incentive to resist the new technology. Atkin et al. argue that a new labor contract compensating workers for the short-run loss in productivity and committing employers to share the gain in long-run productivity (or reduced costs) would help diffuse the new technology.

The problem with viewing technology change as just a technical question of optimal contracts is the underlying political economy. Workers in Pakistan do not generally have written contracts and even if they did, they would not be enforceable in court. As of May 2009, for example, there were more than 100,000 cases pending before the Karachi city courts and 110 judges to try them in a city of 17 million people (Lieven, 2011). Any change in contracts would have to rely on the trust between employers and workers. Without detailed fieldwork on the Sialkot case study, it is difficult to make a specific judgment. In general, though, labor relations in Pakistan are characterized by a lack of cooperation, absent long-term relations and high turnover of labor, which together undermine the credibility of any such long-term promises (Amjad, 2005; Lieven, 2011). What, then, are the broader constraints relating to repression and compensation that were discussed in the opening part to this section?

There are many mechanisms that successful developing and developed countries have used in the historical and contemporary eras to 'solve' the problem of conflict and technological change. The lifetime employment in large Japanese firms that helps ensure workers will eventually benefit from any new technology (Francks, 1999, chap. 12) is not viable in contemporary Pakistan, given the high labor turnover and informality that characterizes most employment.

Other examples include high levels of trust in society that can help employers make credible promises to share the future benefits of technological change with workers (Fukuyama, 1996); well-functioning labor markets and a well-developed social security system that mitigates the downside of technologically induced unemployment (Rodrik, 1998); a corporatist economic structure that enforces a sharing of the economic gains of technological change between labor, corporations and the state (Calmfors \& Driffill, 1988); a well-developed legal system that enables 
workers to negotiate and enforce contracts to ensure they will benefit from technological change in the long run (Easterly, 2001b) and strong trade unions that are able to enforce a sharing of the benefits of technological change with current employees (Miyamura, 2011). It is beyond the scope of this paper but, hopefully, part of a forthcoming research agenda to detail why each of these is not relevant for contemporary Pakistan.

In South Asia, the most important institution to bind different groups into a long-term project of compensation has been the political party. The best example of this is the Congress Party in India, principally between independence and the mid-1960s, the main feature of which was an elaborate system of factions at every level of political and government activity through which Congress functioned (Menon, 2003, pp. 24, 48). The party provided a system of coordination between the various levels through vertical faction chains that "provided a subtle and resilient mechanism for conflict management and transactional negotiations among the proprietary classes" (Bardhan, 1984, p. 77).

The Congress provided a well-defined network for the distribution of the spoils of office, institutionalized procedures of transaction and absorbed dissent by co-opting leaders of subordinate classes (Kothari, 1964). In power between the 1950s and 1980s, Congress monopolized patronage resources right down to the village panchayats, sugar cooperatives, banking corporations and state-allocated resources such as licenses, fertilizer, seeds and road construction. Even those losing out in the short run had an incentive to remain within the party and hope for benefits in the long run. The central leadership provided a system of mediation, arbitration and inter-level coordination in the party.

The Congress system allowed groups losing out from the pattern of economic development to be incorporated and compensated at minimal cost. A good example is the demobilization of a militant labor movement in the late 1940s (Chibber, 2003, chap. 4). After 1945, India faced an explosion of strikes and union activity as real wages were eroded by postwar inflation. In December 1947, a tripartite conference was held to end hostilities. The result was a set of labor laws that undermined the potency of collective bargaining by making unions dependent on state patronage and also engineered a split in the union movement. A new federation, the Indian National Trade Union Congress (INTUC) was formed and affiliated to Congress. Every affiliated organization was compelled to submit to arbitration when industrial disputes were not resolved by negotiation. Under government patronage, the INTUC grew rapidly to become the 
largest labor organization in the country. Labor and union leaders were absorbed into the Congress party, strike activity quickly dropped down to prewar levels and radical labor ceased to be a threat.

Without the distraction of union opposition, the government was better able to pursue its development strategy. This strategy combined efforts to mobilize resources through regressive excise duties to fund large increases in public investment in the 1950s to the 1970s in heavy and chemical industries. This, in turn, helped drive economic growth and industrial diversification (McCartney, 2009). While real wages failed to increase during these years - resources being devoted instead to savings, taxation and investment - workers did receive employment protection, leave, holidays, promotion, wage scales and employment that were regulated by government legislation. The party system enabled the state to focus on long-term growth and compensate those losing out.

The long-standing contrast with Pakistan is striking. While the Indian Congress system retained flexibility in incorporating a diverse array of elites into its ranks, in Pakistan, the Muslim League was more inclined to confront those who contested its hegemonic claims. ${ }^{4}$ The well-organized system of factions of the Congress contrasted with the lack of organizational machinery linking the central leadership of the Muslim League with those exercising power at the provincial and local levels (Jalal, 1990). The monopoly of patronage resources held by the electorally dominant Congress contrasted with the electoral collapse of the Muslim League soon after independence. In the 1954 East Pakistan provincial election, the ruling Muslim League won only 10 out of 309 seats.

The importance of the political party as a means to control the conflicts associated with economic growth and technological change has been widely discussed in the case of India. These efforts, among various others, include the state-level differences relating to poverty reduction (Harriss, 2000), policy implementation (Swaminathan, 1990) and developmentalism by state-level governments (Sinha, 2005) in the recent growth and development success of Bihar (Kumar, 2013) and longstanding welfare success of Kerala (Heller, 1996).

Research related to Pakistan, save the perceived failure of the Muslim League in the years after independence, remains limited. One exception is Lieven (2011) who discusses the Karachi-based MQM in some

\footnotetext{
${ }^{4}$ This section draws from McCartney (2011).
} 
detail. The MQM utilize a mixture of brutality, mobilization, incorporation and compensation to achieve long-term development goals. The MQM, he argues, is very well organized with a strong leadership and clear ideological appeal. The party has shown a capacity to use this to promote long-run economic growth and technological upgrading in Karachi, particularly in regard to communications.

These failed efforts at both incorporation and repression are evident in contemporary Pakistan and contributed to the failure to sustain the incipient economic boom that began in 2003. Around 2003, economic growth surged to over 7 percent for several years. This was related to the rebalancing of the economy away from consumption to investment. Investment surged from 16-17 percent of GDP in 2003 to 23-24 percent of GDP in 2007; the macroeconomic space for this increase was created by efforts to control consumption.

Figure 8 shows that consumption as a share of GDP stabilized or declined in Pakistan around 2000. The shock of the 1999 coup briefly cowed civil society and allowed the incoming Musharraf government this degree of autonomy to restrain consumption and boost productive investment (McCartney, 2015). In India, an equivalent growth boom was supported by a more determined control of consumption, which permitted investment to rise to 35 percent. In China, the squeeze on consumption and rise in investment was even more marked.

\section{Figure 8: Household final consumption expenditure as a share of GDP}

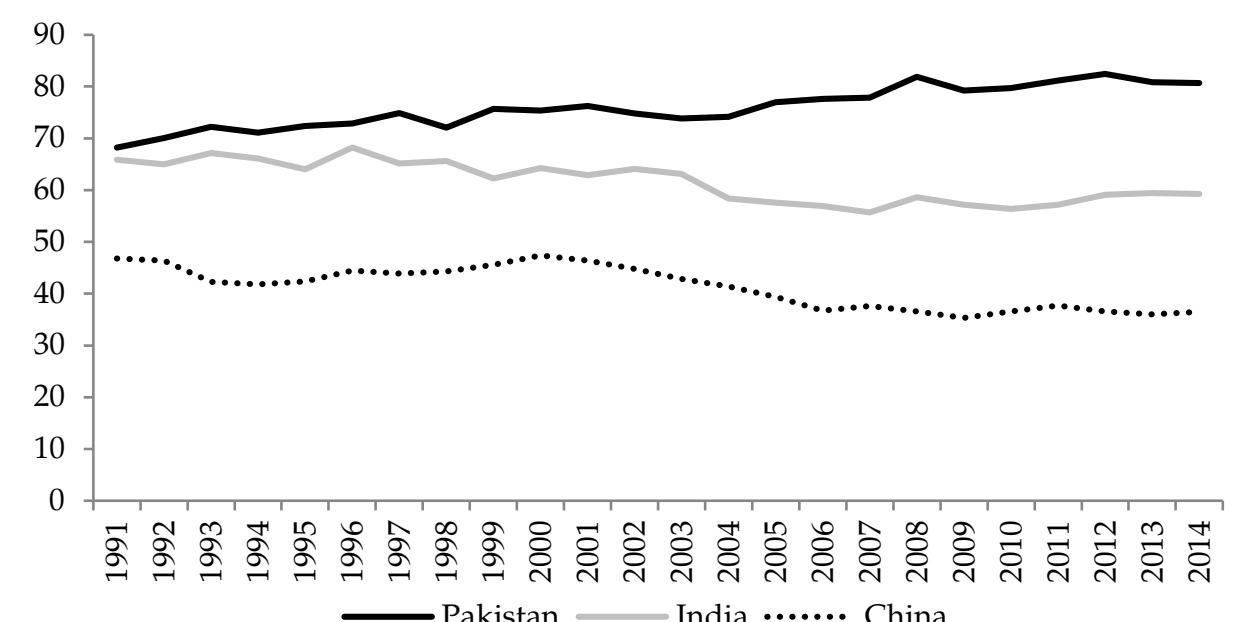

Source: World Bank (2016). 
After 2002, society began reasserting itself and forced Musharraf under growing political pressure to boost populist consumption. In the 2002 elections, an Islamic alliance (the MMA) came to power in Khyber Pakhtunkhwa and won almost 12 percent of the national vote and 62 National Assembly seats (from 342). The PPP emerged as the biggest party but won less than 26 percent of the vote, while the hastily assembled collection of co-opted pro-military notables in the pro-Musharraf PML-Q won around 25 percent of the vote and the PML-N under Nawaz Sharif won less than 10 percent. The vote marked an extreme fragmentation of politics, with each province being won by a different political grouping. Musharraf's new political grouping had comprehensively failed to integrate even the elites, let alone other civil society organizations such as labor, the middle classes and religious groups.

In 2003, the US attacked Iraq and support for the government continued to fall rapidly; it was no surprise that Musharraf declined to step down as army chief of staff in 2004. In terms of reforms "on most key issues he backtracked under pressure from his own right-wing allies and the mullahs" (Hussain, 2010, p. 183). By 2007, massive opposition to Musharraf had emerged with the lawyers' movement, which originated in attempts by Chief Justice Iftikhar Chaudhry to place limits on Musharraf's power in early 2007. The former's consequent dismissal led to a protest movement of lawyers (Lieven, 2011).

The early focus of the Musharraf government on long-term structural reforms, reducing deficits and boosting investment dissolved into a populist effort to buy off growing political opposition. Bank lending went increasingly into lending to consumers rather than funding industrial investment. In the early 2000s, imports and pricing of petroleum products had been deregulated and an automatic price adjustment formula for consumer prices of petroleum products linked with international prices was adopted (Husain, 2003). As Musharraf's popularity declined in the later 2000s, consumers were instead protected from rising oil prices and consumer prices restrained through substantial government budget outlays on subsidies. The wages of public employees were increased. The central government budget went into sharp deficit. Efforts at both incorporation and repression had failed; consumption increased, investment fell and economic growth dropped back to its longer-term average of around $4-5$ percent. 


\section{Conclusion}

This paper has demonstrated that Pakistan has a long-term productivity problem. Though productivity is influenced by many factors, one of the most important is the ability of a country to absorb, adapt, diffuse and successfully utilize new technologies. This paper has looked at long-term influences on that process, focusing on resources (cash), FDI (costs), learning (capabilities) and conflict. In each case, the paper concludes that Pakistan is ill positioned to overcome these specific constraints. Long-term sustainable growth of $7+$ percent, as was experienced briefly in the years after 2003, looks unlikely. Pakistan faces an economic future more like that of Brazil than that of South Korea.

Rather than striving to learn from the impossible - Pakistan is not going to construct a South Korean developmental state of 1961 vintage Pakistan can look instead to the practical. Bangladesh is similar to Pakistan in terms of corruption, weak governance institutions and an intensely politicized, but not ideological, policymaking process by weakly organized political parties. The state has in response decentralized and delegated much policymaking to private organizations such as the Bangladesh Garment Manufacturers and Exporters Association (BGMEA) and the Bangladesh Knitwear Manufacturers and Exporters Association. The delegation of authority to the BGMEA to issue trade (import) customs certificates streamlined the process for garment manufacturers to acquire imported raw materials and technology. To facilitate export financing without government subsidies in 1986/87, the government implemented a back-to-back letter of credit (L/C) system that reduced the problems of financing working capital for garment manufacturers.

The system works in a way that does not require garment manufacturers (or the government) to invest money to open import L/Cs or to pay the fabric suppliers from their own resources. This system is not vulnerable to the budget constraints that undermined the 2009 textiles policy in Pakistan. The operation of the back-to-back L/C ensured garment exporters almost 70 percent of the working capital they needed. Most garment exporters agree that the $\mathrm{L} / \mathrm{C}$ is the most important factor responsible for the rapid growth of garment exports (Ahmed, Greenleaf \& Sacks, 2014). The state has turned its attention to working within annual growth of around 5 percent and channeling the resources generated into improving social welfare, such that Bangladesh is now increasingly discussed as a human development success story (Drèze \& Sen, 2013). If a middle-income trap beckons, then a long-term residence there need not be so bad. 


\section{References}

Ahmed, F. Z., Greenleaf, A., \& Sacks, A. (2014). The paradox of export growth in areas of weak governance: The case of the readymade garment sector in Bangladesh. World Development, 56, 258-271.

Amjad, R. (2005). Skills and competitiveness: Can Pakistan break out of the low-level skills trap? Pakistan Development Review, 44(4), 387409 .

Amsden, A. H., \& Hikino, T. (2000). The bark is worse than the bite: New WTO law and late industrialization. Annals of the American Academy of Political and Social Science, 570, 104-114.

Asian Productivity Organization. (2013). APO productivity databook 2013. Tokyo: Keio University Press.

Atkin, D., Chaudhry, A., Chaudry, S., Khandelwal, A. K., \& Verhoogen, E. (2015). Organizational barriers to technology adoption: Evidence from soccer-ball producers in Pakistan (Working Paper No. 21417). Cambridge, MA: National Bureau of Economic Research.

Bardhan, P. (1984). The political economy of development in India. New Delhi: Oxford University Press.

Burki, A. A., \& Terrell, D. (1998). Measuring production efficiency of small firms in Pakistan. World Development, 26(1), 155-169.

Calmfors, L., \& Driffill, J. (1988). Bargaining structure, corporatism and macroeconomic performance. Economic Policy, 3(6), 13-61.

Chang, H.-J. (1993). The political economy of industrial policy in Korea. Cambridge Journal of Economics, 17, 131-157.

Chang, H.-J. (1999). The economic theory of the developmental state. In M. Woo-Cumings (Ed.), The developmental state (pp. 182-199). Ithaca, NY: Cornell University Press.

Cheema, A. A. (1978). Productivity trends in the manufacturing industries. Pakistan Development Review, 17(1), 44-65.

Chibber, V. (2003). Locked in place: State-building and late industrialization in India. Princeton, NJ: Princeton University Press. 
Clark, G. (2007). A farewell to alms: A brief economic history of the world. Princeton, NJ: Princeton University Press.

Das, J., Pandey, P., \& Zajonc, T. (2012). Learning levels and gaps in Pakistan: A comparison with Uttar Pradesh and Madhya Pradesh. Economic and Political Weekly, 47(26-27), 228-240.

De Soto, H. (2001). The Mystery of Capital: Why Capitalism Triumphs in the West and Fails Everywhere Else. London: Black Swam Books.

Deininger, K., \& Jin, S. (2003). Land sales and rental markets in transition: Evidence from rural Vietnam. Oxford Bulletin of Economics and Statistics, 70(1), 67-101.

Di Caprio, A., \& Amsden, A. (2004). Does the new international trade regime leave room for industrialization policies in the middle-income countries? (Working Paper No. 22). Geneva: International Labour Office, World Commission on the Social Dimension of Globalization.

Din, M., Ghani, E., \& Mahmood, T. (2007). Technical efficiency of Pakistan's manufacturing sector: A stochastic frontier and data envelopment analysis. Pakistan Development Review, 46(1), 1-18.

Drèze, J., \& Sen, A. (2013). An uncertain glory: India and its contradictions. London: Allen Lane.

Easterly, W. (2001a). The elusive quest for growth: Economists' adventures and misadventures in the tropics. Cambridge, MA: MIT Press.

Easterly, W. (2001b). Can institutions resolve ethnic conflict? Economic Development and Cultural Change, 49(4), 687-706.

Ermisch, J. F., \& Huff, W. G. (1999). Hypergrowth in an East Asian NIC: Public policy and capital accumulation in Singapore. World Development, 27(1), 21-38.

Felipe, J., Abdon, A., \& Kumar, U. (2012). Tracking the middle-income trap: What is it, who is in it and why? (Working Paper No. 715). New York, NY: Levy Economics Institute of Bard College.

Francks, P. (1999). Japanese economic development: Theory and practice. London: Routledge. 
Fukuyama, F. (1996). Trust: The social virtues and the creation of prosperity. London: Penguin.

Gorg, H., \& Greenaway, D. (2004). Much ado about nothing? Do domestic firms really benefit from foreign direct investment? World Bank Research Observer, 19(2), 171-197.

Harriss, J. (2000). How much difference does politics make? Regime differences across Indian states and rural poverty reduction (DESTIN Working Paper No. 1). London: Development Studies Institute.

Heller, P. (1996). Social capital as a product of class mobilization and state intervention: Industrial workers in Kerala, India. World Development, 24(6), 1055-1071.

Hoekman, B. M., Maskus, K. E., \& Saggi, K. (2005). Transfer of technology to developing countries: Unilateral and multilateral policy options. World Development, 33(10), 1587-1602.

Hsieh, C.-T., \& Klenow, P. J. (2007). Misallocation and manufacturing TFP in China and India. Unpublished manuscript, University of California, Berkeley, CA.

Huff, W. G. (1995). What is the Singapore model of economic development? Cambridge Journal of Economics, 19(6), 735-759.

Huntingdon, S.P. (1968). Political Order in Changing Societies. New Haven: Yale University Press.

Husain, I. (2003). Economic management in Pakistan, 1999-2002. Karachi: Oxford University Press.

Hussain, Z. (2010). Frontline Pakistan: The path to catastrophe and the killing of Benazir Bhutto. New York: I. B. Tauris.

Jalal, A. (1990). The state of martial rule: The origins of Pakistan's political economy of defense. Cambridge: Cambridge University Press.

Johnson, C. (1982). MITI and the Japanese miracle: The growth of industrial policy, 1925-1975. Stanford, CA: Stanford University Press. 
Kenoyer, J. M. (1997). Trade and technology of the Indus Valley: New insights from Harappa, Pakistan. World Archaeology, 29(2), 262280.

Khan, M. H. (2008). Technological upgrading in Bangladeshi manufacturing: Governance constraints and policy responses in the readymade garments industry. Unpublished manuscript, School of Oriental and African Studies, London.

Khan, M. H. (2011). The economic development of Bangladesh: Identifying pragmatic policy responses. In M. Ullah (Ed.), Bangladesh tomorrow (pp. 11-68). Dhaka: Center for Sustainable Development.

Khan, M. H. (2013a). Technology policies and learning with imperfect governance. In J. Stiglitz and J. Y. Lin (Eds.), The industrial policy revolution I: The role of government beyond ideology. London: Palgrave.

Khan, M. H. (2013b). Political settlements and the design of technology policy. In J. Stiglitz, J. Y. Lin \& E. Patel (Eds.), The industrial policy revolution II: Africa in the twenty-first century. London: Palgrave.

Khan, M. H., \& Blankenburg, S. (2006). The political economy of industrial productivity in Asia and Latin America. In M. Cimoli, G. Dossi \& J. Stiglitz (Eds.), Industrial policy and development. Oxford: Oxford University Press.

Khan, S. H. (2009). Making people employable: Reforming secondary education in Pakistan. Pakistan Development Review, 48(4), 603-617.

Kharas, H., \& Kohli, H. (2011). What is the middle income trap, why do countries fall into it, and how can it be avoided? Global Journal of Emerging Market Economies, 3(3), 281-289.

Khwaja, A. I., \& Mian, A. (2005). Do lenders favor politically connected firms? Rent provision in an emerging financial market. Quarterly Journal of Economics, 120(4), 1371-1411.

Kohli, A. (2004). State-directed development: Political power and industrialization in the global periphery. Cambridge: Cambridge University Press. 
Kothari, R. (1964). The Congress 'system' in India. Asian Survey, 4(12), 1161-1173.

Krieckhaus, J. (2002). Reconceptualizing the developmental state: Public savings and economic growth. World Development, 30(10), 16971712 .

Kumar, A. (2013). Development focus and electoral success at state level: Nitish Kumar as Bihar's leader. South Asia Research, 33(2), 101-121.

Lall, S. (1992). Technological capabilities and industrialization. World Development, 20(2), 165-186.

Lall, S. (1994). The East Asian miracle: Does the bell toll for industrial strategy? World Development, 22(4), 645-654.

Leftwich, A. (1995). Bringing politics back in: Towards a model of the developmental state. Journal of Development Studies, 31(3), 400-427.

Levien, M. (2011). Special economic zones and accumulation by dispossession in India. Journal of Agrarian Change, 11(4), 454-483.

Lieven, A. (2011). Pakistan: A hard country. London: Allen Lane.

Mardon, R. (1990). The state and the effective control of foreign capital: The case of South Korea. World Politics, 43(1), 111-138.

McCartney, M. (2009). India - The political economy of growth, stagnation and the state, 1951-2007. London: Routledge.

McCartney, M. (2011). Pakistan - The political economy of growth, stagnation and the state, 1951-2009. London: Routledge.

McCartney, M. (2012). Competitiveness and Pakistan: A dangerous, distorting and dead-end obsession [Special edition]? Lahore Journal of Economics, 17, 213-241.

McCartney, M. (2014). The political economy of industrial policy: A comparative study of the textiles industry in Pakistan [Special edition]. Lahore Journal of Economics, 19, 105-134. 
McCartney, M. (2015). From boom to bust: Economic growth and security in Pakistan 2003-2013. In S. Gregory (Ed.), Democratic transition and security in Pakistan (chap. 4). London: Routledge.

Menon, V. (2003). From movement to government: The Congress in the United Provinces, 1937-42. New Delhi: Sage.

Miyamura, S. (2011). Diversity of labor market institutions in Indian industry: A comparison of Mumbai and Kolkata. Indian Journal of Labour Economics, 54(1), 113-130.

Mohanty, M. (2007). Political economy of agrarian transformation: Another view of Singur. Economic and Political Weekly, 42(9), 737-741.

Nelson, R. \& Pack, H. (1999). The Asian Miracle and Modern Economic Growth, Economic Journal, 109, 416-436.

Ó Riain, S. (2000). The flexible developmental state: Globalization, information technology and the "Celtic tiger." Politics and Society, 28(2), 157-193.

Raheman, A., Afza, T., Qayyum, A., \& Bodla, M. A. (2008). Estimating total factor productivity and its components: Evidence from major manufacturing industries of Pakistan. Pakistan Development Review, 47(4), 677-694.

Ravallion, M., \& Van De Walle, D. (2006). Land reallocation in an agrarian transition. The Economic Journal, 116(514), 924-942.

Rodrik, D. (1998). Why do more open economies have bigger governments? Journal of Political Economy, 106(5), 997-1032.

Sarkar, A. (2007). Development and displacement: Land acquisition in West Bengal. Economic and Political Weekly, 42(16), 1435-1442.

Sinha, A. (2005). The regional roots of developmental politics in India. Indianapolis, IN: Indiana University Press.

Swaminathan, M. (1990). Village-level implementation of IRDP: Comparison of West Bengal and Tamil Nadu. Economic and Political Weekly, 25(13), 17-27. 
Wade, R. H. (2003). What strategies are viable for developing countries today? The World Trade Organization and the shrinking of 'development space'. Review of International Political Economy, 10(4), 621-644.

Weiss, L. (2005). Global governance, national strategies: How industrialized states make room to move under the WTO. Review of International Political Economy, 12(5), 723-749.

Weyland, K. (1998). From Leviathan to Gulliver? The decline of the developmental state in Brazil. Governance, 11(1), 51-75.

Wizarat, S. (2002). The rise and fall of industrial productivity in Pakistan. Karachi: Oxford University Press.

Wolcott, S., \& Clark, G. (1999). Why nations fail: Managerial decisions and performance in Indian cotton textiles, 1890-1938. Journal of Economic History, 59(2), 397-423.

World Bank. (2007). Pakistan - Enterprise survey 2007. Available from http://microdata.worldbank.org/index.php/catalog/659

World Bank. (2016). World development indicators. Accessed 15 March 2016, from http://data.worldbank.org/data-catalog/worlddevelopment-indicators

World Economic Forum. (2006). The global competitiveness report, 20062007. Basingstoke: Palgrave Macmillan.

World Economic Forum. (2014). The global competitiveness report, 20142015. Geneva: Author. 